\title{
The Cell Cycle of the Budding Yeast Sterigmatomyces halophilus: Culture Fractionation by Zonal Centrifugation and the Accumulation of DNA, RNA and Protein
}

\author{
By IAN SALMON† AND ROBERT K. POOLE* \\ Department of Microbiology, Queen Elizabeth College, University of London, Campden Hill, \\ London W8 7 AH, U.K. \\ (Received 21 September 1982; revised 29 December 1982)
}

\begin{abstract}
Sterigmatomyces halophilus is an unusual budding yeast in which daughter cells are formed, remote from the mother cell, on fine projections called sterigmata. Some fundamental properties of the cell cycle have been explored by separating cells from an exponentially growing culture into size, and thus age, classes by density-gradient centrifugation. Rate separations on high capacity, high resolution, equivolumetric gradients of sucrose, or, alternatively, isopycnic separations on gradients of Urografin revealed consistent and reproducible patterns of accumulation of DNA, RNA and protein through the cell cycle. Total DNA accumulation was stepwise, synthesis occurring late in the cycle, whilst protein accumulated continuously with no evidence for the discontinuities reported in some other lower eukaryotes. Total RNA accumulation, measured either colorimetrically or by long-term incorporation of radioactivelylabelled uracil was transiently elevated early in the cycle and then accumulated continuously. A mathematical analysis of the volume distributions of the cells in fractions from the gradients showed that there is a hyperbolic relationship between cell age and size but that, to a first approximation, measurements of cell size (and density) are direct measures of age. The results are discussed with reference to (1) the unusually high buoyant density of this yeast, (2) the resolution of zonal cell separation methods and (3) macromolecular accumulation in the cell cycles of other eukaryotic micro-organisms.
\end{abstract}

\section{INTRODUCTION}

The cell cycle is characterized by a recurrent series of discrete events. Nucleic acids, proteins and all cellular constituents approximately double in amount during its progress, prior to segregation at cell division. In eukaryotes, DNA replication is restricted to a discrete portion of the cell cycle, the S phase, whereas total RNA and protein are generally considered to be continuously synthesized. Recently, however, evidence has been obtained for discontinuous accumulation of macromolecules and oscillatory expression of respiratory activity during the cell cycles of various eukaryotic micro-organisms (Edwards \& Lloyd, 1980; Lloyd et al., 1981).

With a view to studying the distribution of mitochondrial components between mother and bud cells in the yeast cell cycle, we selected an organism for study, Sterigmatomyces halophilus, that seemed to have a special advantage, namely that developing buds are formed at the ends of fine projections (sterigmata) from the wall of the mother cell (Fell, 1966). Should these sterigmata prove susceptible to rupture, a method would be available for the removal, separation and characterization of buds at various stages of maturity. Since we are unaware of any work on the cell cycle of this organism, it was first necessary to develop methods of cell cycle analysis and study the synthesis of mitochondrial and other macromolecules.

Cell cycle fractionation requires physical separation of cells from exponentially growing cultures into sub-populations of cells that are homogeneous with respect to age. Usually, such fractionations involve sedimentation through density gradients and resolve cells into size

$\dagger$ Present address: Biological Laboratory, The University, Canterbury, Kent CT2 7NJ, U.K. 
classes. However, a cell about to divide sediments only $41 \%$ faster than either of the resulting daughter cells (Koch \& Blumberg, 1976). This compression of the twofold range of mass (or volume) encountered during the cell cycle means that fractionations must be of high resolution to be of value. In zonal rotors, best resolution is attained on equivolumetric gradients, in which particles move through equal volumes of medium in equal time units and at velocities proportional to their sedimentation coefficients (Pollack \& Price, 1971); this is achieved by counterbalancing the tendency of particles to accelerate (due to the increased centrifugal force at greater radii) by the increase in viscosity and density of the supporting medium. Alternatively, cells may be centrifuged to equilibrium in the density gradient (isopycnic sedimentation). Little use has been made of this technique in cell cycle analysis because, unlike size, the relationship between density and cell age may be complicated.

This investigation examines the patterns of protein, RNA and DNA synthesis during the cell cycle of $S$. halophilus as revealed by age fractionation of exponentially growing cultures. The results obtained by rate sedimentation through equivolumetric sucrose gradients and by isopycnic (equilibrium) sedimentation are essentially similar, and show a continuous accumulation for total protein but discontinuous patterns for RNA and DNA.

Parts of this work have been published previously in abstract form (Salmon \& Poole, 1978).

\section{METHODS}

Organism, maintenance and growth. Sterigmatomyces halophilus CBS 4609 (obtained from the Centraalbureau voor Schimmelcultures, Yeast Division, Delft, The Netherlands) was maintained on a solid, complex medium and grown in a defined liquid medium with glucose as the growth-limiting substrate (Salmon \& Poole, 1980).

Harvesting of organisms. After about $32 \mathrm{~h}$ growth, when the culture was in the exponential phase of growth (mean generation time $6.0 \mathrm{~h}$ ) and the cell count was $2 \times 10^{7}$ to $3 \times 10^{7}$ cells $\mathrm{ml}^{-1}$, cells were collected by passing the culture at 1 litre $\mathrm{min}^{-1}$ through an MSE continuous action rotor fitted with a high-efficiency insert, operating at 15000 r.p.m. at $4{ }^{\circ} \mathrm{C}$ in an MSE 18 centrifuge. Cells were harvested from the resultant concentrated suspension and washed once with $3 \%(\mathrm{w} / \mathrm{v}) \mathrm{NaCl}$ by acceleration to $10000 \mathrm{r} . \mathrm{p} . \mathrm{m}$. in the $6 \times 250 \mathrm{ml}$ rotor of the same centrifuge, followed by immediate deceleration.

Rate-zonal culture fractionations. These were performed at $4{ }^{\circ} \mathrm{C}$ in an MSE HS zonal rotor in an MSE 18 centrifuge fitted with a low speed zonal control. This rotor has a volume of $695 \mathrm{ml}$. Gradients were formed from unbuffered sucrose solutions in $3 \%(\mathrm{w} / \mathrm{v}) \mathrm{NaCl}$; the $\mathrm{pH}$ of these solutions was not lower than 5 . An equivolumetric gradient (Pollack \& Price, 1971) was calculated, using a boundary condition of $41 \%$ (w/w) sucrose at $30 \mathrm{ml}$ (radius $=4.35 \mathrm{~cm}$ ) and a value of $1.245 \mathrm{~g} \mathrm{ml}^{-1}$ (see below) for the mean density of $S$. halophilus. The gradient was convex in shape, with a maximum sucrose concentration at the rotor edge of $48.5 \%(\mathrm{w} / \mathrm{w})$. During loading, the rotor was run at 600 r.p.m. and the gradient generated using a programmable gradient former (Mix-o-grad; Gilson, 69-72 Rue Gambetta, 95400 Villiers le Bel, France) from two solutions having concentrations equal to those at the edge and centre, respectively, of the complete gradient. Routinely, cells from 5 to 101 of exponentially growing culture were harvested and resuspended to about $15 \mathrm{ml}$ in $41 \%(\mathrm{w} / \mathrm{w})$ sucrose. This suspension $\left(6 \times 10^{9}\right.$ to $20 \times 10^{9}$ cells $\mathrm{ml}^{-1}$ ) was homogenized with two strokes of a loose-fitting Dounce homogenizer and pumped on to the gradient at about $20 \mathrm{ml} \mathrm{min}^{-1}$; this was followed by an overlay $(15 \mathrm{ml})$ of $20 \%(\mathrm{w} / \mathrm{w})$ sucrose. The rotor was capped and accelerated to 8800 r.p.m. for about $8 \mathrm{~min}\left(6600 \mathrm{~g}, r_{\mathrm{av}} .7 .58 \mathrm{~cm}\right)$. The rotor was then decelerated to 600 r.p.m. and the gradient unloaded by displacement with $60 \%(\mathrm{w} / \mathrm{w})$ sucrose at about $40 \mathrm{ml} \mathrm{min}^{-1}$. Fractions (about $20 \mathrm{ml}$ ) were collected in $50 \mathrm{ml}$ centrifuge tubes on ice and the cells harvested by acceleration to 12000 r.p.m., followed by immediate deceleration in the $8 \times 50 \mathrm{ml}$ rotor of an MSE 18 centrifuge. A portion of the supernatant was retained for determination of sucrose. The pellets were washed twice with, and finally resuspended in, $3 \%(\mathrm{w} / \mathrm{v}) \mathrm{NaCl}$. This removed sucrose that interferes in the assays for protein and nucleic acid (Hartman et al., 1974). The integrated force-time from loading until half the gradient had been expelled was $\int_{0}^{t} \omega^{2} . \mathrm{dt}=7 \cdot 17 \times 10^{8} \mathrm{rad}^{2} \mathrm{~s}^{-2}$.

Isopycnic-zonal culture fractionations. These were performed in an aluminium BXIV zonal rotor (total capacity $650 \mathrm{ml}$ ) operating at $4{ }^{\circ} \mathrm{C}$ in an MSE 65 centrifuge. Separations were carried out on $200 \mathrm{ml}$ gradients of 26 to $44 \%$ $(\mathrm{w} / \mathrm{v})$ Urografin 370 (a mixture of sodium diatrizoate and meglumine diatrizoate) in $3 \%(\mathrm{w} / \mathrm{v}) \mathrm{NaCl}(\rho=1 \cdot 16$ to $1.27 \mathrm{~g} \mathrm{ml}^{-1}$ ), which were linear with volume. The remaining volume of the rotor was filled with a $350 \mathrm{ml}$ overlay of 2.5 to $22.5 \%(\mathrm{w} / \mathrm{v})$ Urografin and a $100 \mathrm{ml}$ cushion of $45 \%$ (w/v) Urografin both in $3 \%(\mathrm{w} / \mathrm{v}) \mathrm{NaCl}$. The overlay (which occupied the space nearest the core) consisted of [percentage (w/v) Urografin in $3 \%(w / v) ~ N a C l]$ : $160 \mathrm{ml}, 2.5 ; 80 \mathrm{ml}, 7.5 ; 50 \mathrm{ml}, 12.5 ; 40 \mathrm{ml}, 17.5 ; 20 \mathrm{ml}, 22.5$. These steps gave a density profile that was exponential with respect to volume. The large cushion (which occupied the space nearest the edge of the rotor) was required to prevent diffusion of the sucrose solution, the displacement medium used for unloading, into the 
gradient. The rotor was loaded manually at 2500 r.p.m. with cold gradient solutions at about $15 \mathrm{ml} \mathrm{min}^{-1}$. Cells from 5 to $10 \mathrm{l}$ of exponentially growing culture were harvested and resuspended in $3 \%(\mathrm{w} / \mathrm{v}) \mathrm{NaCl}$ to about $15 \mathrm{ml}$ with two strokes of the homogenizer (and at approx. $2 \times 10^{10} \mathrm{cells} \mathrm{ml}^{-1}$ ). The suspension was introduced into the rotor at $15 \mathrm{ml} \mathrm{min}^{-1}$ and followed by $15 \mathrm{ml}$ of $3 \%(\mathrm{w} / \mathrm{v}) \mathrm{NaCl}$. The rotor was capped and accelerated to 30000 r.p.m. $(25000 \mathrm{~g}$, radius at sample zone $2.48 \mathrm{~cm}$ ). After $60 \mathrm{~min}$, the rotor was decelerated to 2500 r.p.m. and the contents displaced with $61 \%(\mathrm{w} / \mathrm{w})$ sucrose in $3 \%(\mathrm{w} / \mathrm{v}) \mathrm{NaCl}\left(\rho=1.33 \mathrm{~g} \mathrm{ml}^{-1}\right)$ at about $20 \mathrm{ml} \mathrm{min}^{-1}$. After $370 \mathrm{ml}$ had been expelled from the rotor, fractions (between 5 and $20 \mathrm{ml}$ ) were collected in $50 \mathrm{ml}$ centrifuge tubes until the effluent was clear and a total volume of $540 \mathrm{ml}$ had been displaced. A small portion of each fraction was retained for the determination of density. The remainder of each was diluted with an equal volume of $3 \%(w / v)$ $\mathrm{NaCl}$ and the cells harvested by acceleration to 12000 r.p.m. in the $8 \times 50 \mathrm{ml}$ rotor, followed by immediate deceleration. The pellets were washed twice and finally resuspended in $3 \%(\mathrm{w} / \mathrm{v}) \mathrm{NaCl}$. This extensive washing removed Urografin, which interferes in the Lowry assay by forming an intense black colour (Hinton et al., 1974), and also in the UV determination of RNA in cell extracts by the strong absorption of the diatrizoate at $260 \mathrm{~nm}$ (Hinton \& Mullock, 1975). The integrated force-time from loading until half the gradient had been expelled was $\int_{0}^{t} \omega^{2} \cdot \mathrm{dt}=3.56 \times 10^{10} \mathrm{rad}^{2} \mathrm{~s}^{-2}$.

Cell counting and sizing. All determinations of cell population densities were performed with a Coulter Counter Model $Z_{B 1}$ (Coulter Electronics, Dunstable, U.K.) using a probe with an aperture diameter of $50 \mu \mathrm{m}$. A Coulter Channelyzer $\mathrm{C} 1000$ provided a visual display of size distribution and, via a Teleprinter Interface to a Westrex teletype, paper tape output suitable for computer analysis (Bazin et al., 1975). Coefficients of variation (S.D./mean) were calculated as described by these authors. Standard deviation was given by $\sqrt{ } v$, where $v=$ $\sum_{100}^{i=1} F_{\mathrm{i}}(V-m)^{2}$ and $F_{\mathrm{i}}=$ frequency of cells in channel $i, V=$ volume of cells in channel $i$, and $m=$ mean cell volume. To minimize electrical and radio interference, the equipment was situated in a large (walk-in) earthed Faraday cage with a stabilized power supply (Pickett \& Lester, 1979). Dilutions for counting were made directly into a buffered electrolyte (Poole, 1977) from which debris had been removed by three passages through $0.2 \mu \mathrm{m}$ filters (Sartorius Membranfilter, type SM11307; V. A. Howe, London SW6, U.K.); typical background counts of less than 150 were obtained. Samples kept in this electrolyte had a constant cell count over long periods ( $48 \mathrm{~h})$, but decreased in volume slowly, the mean cell volume reducing by approx $5 \%$ in $3 \mathrm{~h}$. Therefore, counting and sizing were done immediately upon dilution to give a machine count of between 10000 and 40000 . All cell counts are the means of four determinations and are corrected for coincidence and background count. The coefficient of variation of cell counts on 12 replicate dilutions was $0 \cdot 011$ and for mean cell volume was $7 \cdot 1 \times 10^{-3}(12$ replicate dilutions).

DNA determination. DNA was determined using a semi-micro modification of the Burton (1956) procedure, previously described by Zamb \& Roth (1977). Samples containing about $3 \times 10^{8}$ cells were harvested in $15 \mathrm{ml}$ conical glass centrifuge tubes by centrifugation at $2500 \mathrm{~g}\left(r_{\mathrm{av}}\right.$.) for $10 \mathrm{~min}$ and stored at $-20{ }^{\circ} \mathrm{C}$ until required. Assays were generally performed within $3 \mathrm{~d}$ of storage. The frozen pellets were thawed and resuspended in $8 \mathrm{ml}$ of $0 \cdot 2 \mathrm{M}$-perchloric acid in $50 \%(\mathrm{v} / \mathrm{v})$ ethanol and incubated for $40 \mathrm{~min}$ at room temperature. After this period, the cells were harvested as described above, washed once with $4 \mathrm{ml}$ ethanolic perchloric acid and pelleted once more. A small quantity of acid-washed beads $(100 \mu \mathrm{m}$ diameter $)$ were added to the samples and the pellets homogenized by vortexing the tubes. Fatty substances, which may cause turbidity in the final incubation (Croes, 1967), were removed by two extractions with a hot ethanol/ether mixture $(3: 1, \mathrm{v} / \mathrm{v})$. The samples were treated with $4 \mathrm{ml}$ of this mixture and incubated at $60^{\circ} \mathrm{C}$ for $5 \mathrm{~min}$, then centrifuged as described above and the supernatant carefully removed by aspiration. This procedure was repeated. During these extractions there is no loss of nucleic acids (Munro \& Downie, 1964). The samples and a series of standards [0 to $200 \mu$ l of a stock solution of highly polymerized calf thymus DNA $\left(100 \mu \mathrm{g} \mathrm{ml}^{-1}\right.$ in $1.5 \mathrm{~mm}$-sodium citrate, $\left.\left.15 \mathrm{mM}-\mathrm{NaCl}, \mathrm{pH} 7.0\right)\right]$ were dried at $55^{\circ} \mathrm{C}$ for 18 to $24 \mathrm{~h}$. The samples and DNA standards were then removed from the oven and allowed to cool to room temperature. Each was treated with $1 \mathrm{ml} 1.0 \mathrm{M}$-perchloric acid, vortexed to homogeneity, and incubated for 30 min at $70{ }^{\circ} \mathrm{C}$ with periodic mixing. When the tubes were cool, $1.0 \mathrm{ml}$ of $4.0 \%(\mathrm{w} / \mathrm{v})$ diphenylamine dissolved in glacial acetic acid, containing $80 \mu \mathrm{g}$ acetaldehyde $\mathrm{ml}^{-1}$, was added. This reagent was freshly prepared just before use. The colour was then allowed to develop for about $18 \mathrm{~h}$ at $30^{\circ} \mathrm{C}$. The samples (but not the standards) were centrifuged for $5 \mathrm{~min}$ at $2500 \mathrm{~g}\left(r_{\mathrm{av}}\right.$ ) to remove any debris, and the supernatants transferred to new tubes. The absorption of the samples and standards was measured at two wavelengths ( 595 and $650 \mathrm{~nm}$ ) as a protection against turbidity (Giles \& Myers, 1965). The difference in absorption was directly proportional to the amount of DNA. This assay was found to be linear to at least $50 \mu \mathrm{g}$ DNA, and with cell numbers to at least $6.5 \times 10^{8}$ cells. A coefficient of variation of 0.04 was found on 15 replicate samples.

RNA determination. RNA was estimated using the procedure of Herbert et al. (1971) and Stewart (1975). Samples containing about $10^{8}$ cells were harvested by centrifugation for $10 \mathrm{~min}$ at $2500 \mathrm{~g}\left(r_{\mathrm{av} .}\right)$ and the pellets stored at $-20^{\circ} \mathrm{C}$ until required. The frozen pellets were treated as described for the DNA assay with $4 \mathrm{ml} 0 \cdot 2 \mathrm{M}-$ perchloric acid in $50 \%(\mathrm{v} / \mathrm{v})$ ethanol and incubated for $40 \mathrm{~min}$ at room temperature. The residue was harvested as described above, washed once with $2 \mathrm{ml}$ ethanolic perchloric acid and pelleted once more. Care was taken to 
ensure that the material was not in contact with the ethanolic perchloric acid for more than 80 min as some loss of RNA may then occur (Croes, 1967). The RNA was extracted by incubating the residue with $2 \mathrm{ml} 0 \cdot 5 \mathrm{M}$-perchloric acid at $37^{\circ} \mathrm{C}$ for $3.5 \mathrm{~h}$. This period was sufficient to ensure complete hydrolysis of the RNA. Longer periods caused an increase in the absorption at $230 \mathrm{~nm}$, indicative of carbohydrate hydrolysis. No extraction of lipids was carried out (as described in Herbert et al., 1971), since no turbidity was observed in the hydrolysate and comparable results were obtained if this treatment was carried out. The debris was removed by centrifugation for $5 \mathrm{~min}$ at $2500 \mathrm{~g}\left(\mathrm{r}_{\mathrm{av}}\right)$ and the absorption of the supernatant at 260 and $230 \mathrm{~nm}$ recorded. A standard curve was prepared using 0 to $80 \mu \mathrm{g}$ of commercially available yeast RNA; the difference in absorption at 260 and $230 \mathrm{~nm}$ was directly proportional to the amount of RNA up to about $50 \mu \mathrm{g}$. The assay was linear with cell numbers to $2 \times 10^{8}$ cells, and had a coefficient of variation of 0.047 on 10 replicate determinations. As a check, RNA was also assayed by the orcinol method of Ceriotti (1955); both methods gave comparable results.

Measurement of the rate of RNA synthesis. The rate of RNA synthesis was measured using a dual-label procedure involving long-term and pulse-labelling of the nucleic acids (Elliott \& McLaughlin, 1978). Small-scale (200 ml) cultures of $S$. halophilus were grown in the presence of $0.5 \mu \mathrm{Ci}(18.5 \mathrm{kBq})\left[{ }^{3} \mathrm{H}\right]$ uracil $\mathrm{ml}^{-1}(0.5 \mathrm{mg}$ total $)$ for about $15 \mathrm{~h}\left(2.5\right.$ generations) and $0.25 \mu \mathrm{Ci}(9.25 \mathrm{kBq})\left[{ }^{14} \mathrm{C}\right]$ uracil ml ${ }^{-1}(0.1 \mathrm{mg}$ total) for a $30 \mathrm{~min}$ pulse (equivalent to 0.08 generations). The incorporation of label was stopped by the addition of frozen medium, containing no label, to the culture. The cells were immediately harvested, washed once and suspended to about $1 \mathrm{ml} \mathrm{in} 3 \%(\mathrm{w} / \mathrm{v}) \mathrm{NaCl}$ before loading on to a $10 \mathrm{ml}$ gradient of 25 to $45 \%(\mathrm{w} / \mathrm{v})\left(\rho=1 \cdot 16\right.$ to $\left.1.28 \mathrm{~g} \mathrm{ml}^{-1}\right)$ Urografin in a $14 \mathrm{ml}$ centrifuge tube. The gradient was linear with respect to volume and contained $3 \%(\mathrm{w} / \mathrm{v}) \mathrm{NaCl}$ throughout. Centrifugation was at $100000 \mathrm{~g}\left(r_{\mathrm{av}} .11 \cdot 1 \mathrm{~cm}\right)$ in a swing-out rotor. Fractions from the gradient were harvested and washed as described above. RNA was extracted as TCA-insoluble material (Wain \& Staatz, 1973) from cell suspensions that were adjusted to contain approximately equal numbers of cells, and radioactivity then determined.

Protein determination. The total protein content of whole cells was determined by the procedure of Herbert et al. (1971). A sample of cell suspension containing about $3 \times 10^{7}$ cells was brought to $0.5 \mathrm{ml}$ with water and digested with $0.5 \mathrm{ml} 1 \mathrm{M}-\mathrm{NaOH}$ for $10 \mathrm{~min}$ at $100^{\circ} \mathrm{C}$ before assay by Lowry's method. Standards were prepared from BSA and treated exactly as described for the samples. Total protein estimates were generally carried out in quadruplicate. The assay was linear with cell numbers to at least $7 \times 10^{7}$ cells and had a coefficient of variation of 0.066 on eight replicate determinations. When many determinations were made, a curve was fitted to the standards according to the hyperbolic relationship of Coakley \& James (1978), a computer program being written to adjust the constants to obtain the best fit to the experimental data. Otherwise, protein values were read directly from a curve fitted by eye.

Sucrose. Sucrose concentrations were determined at room temperature (about $20^{\circ} \mathrm{C}$ ), with an Abbe-type refractometer (Bellingham \& Stanley, London, U.K.) calibrated directly in percentage (w/v). Corrections were made for the refractivity of the supporting medium.

Determination of density. The densities of fractions taken from isopycnic fractionations were determined by one of two methods. First, drops ( 3 to $5 \mu \mathrm{l}$ ) of the aqueous samples were allowed to sediment to equilibrium in a linear non-aqueous density gradient at room temperature (Miller \& Gasek, 1960; Poole, 1977). The gradients used were prepared from kerosene and $\mathrm{CCl}_{4}$ mixtures and were calibrated with drops of $\mathrm{KI}$ solutions whose densities were determined by interpolation of data from International Critical Tables (1928). Second, the intense absorption of Urografin at $260 \mathrm{~nm}$ was exploited as a measure of density. A standard curve relating absorption and density (determined gravimetrically) was prepared. Determinations made by both methods were in good agreement.

Chemicals. AnalaR quality sucrose was obtained from Fisons; Urografin 370 was from Schering Chemicals, Burgess Hill RH15 9NE, U.K.; BSA was from Armour Pharmaceuticals, Eastbourne, U.K.; DNA (highly polymerized, calf thymus) and RNA (sodium salt, from yeast) were from BDH. [2-14C]Uracil (sp.act. $58 \mathrm{mCi} \mathrm{mmol}^{-1} ; 2 \cdot 15 \mathrm{GBq} \mathrm{mmol}^{-1}$ ) and $\left[6-{ }^{3} \mathrm{H}\right]$ uracil (sp.act. $24 \mathrm{Ci} \mathrm{mmol}^{-1} ; 888 \mathrm{GBq} \mathrm{mmol}^{-1}$ ) were from Amersham. 4',6-Diamidino-2-phenylindole was a generous gift from Professor O. Dann, Institut für Angewandte Chemie der Friedrich-Alexander-Universität, Erlangen, G.D.R.

\section{RESULTS}

\section{Rate-zonal fractionations}

The yeast Sterigmatomyces does not utilize sucrose as carbon source (Fell, 1966) and so initial attempts at fractionation were made using gradients similar to those employed by other authors for yeasts: 20 to $40 \%$ (w/w) (Sebastian et al., 1971), 15 to $30 \%$ (w/w) (Wells \& James, 1972), and 15 to $40 \%(\mathrm{w} / \mathrm{w})$ (Poole \& Lloyd, 1973) sucrose gradients that were linear with respect to volume. In all cases, the cells sedimented rapidly as a narrow band, in which there was little or no variation in size. This rapid sedimentation was due to a high buoyant density of the cells, since equilibrium sedimentation (see below) gave an estimate of the mean density of cells from an 


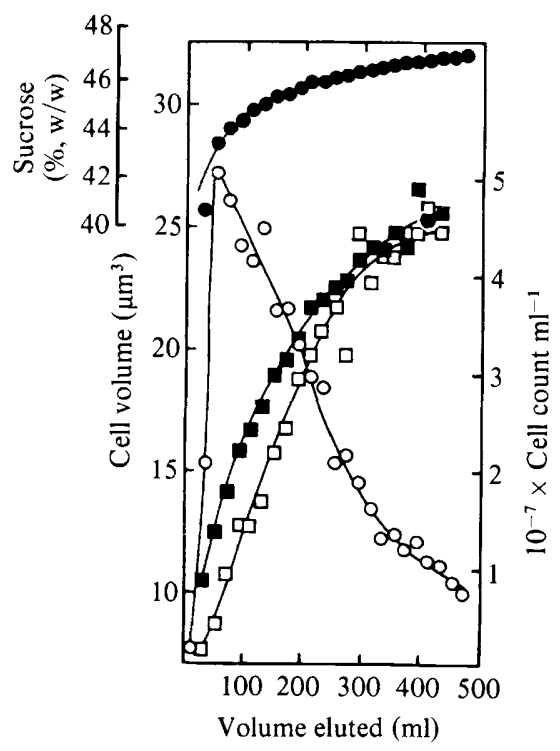

Fig. 1. Rate-zonal fractionation of cells from an exponentially growing culture of $S$. halophilus. A suspension of cells (about $11 \mathrm{ml}$ ) containing $2.4 \times 10^{9}$ cells ml-1 was introduced into the core of an MSE HS zonal rotor. Centrifugation was at 8800 r.p.m. for about $8 \mathrm{~min}\left(6600 \mathrm{~g}, r_{\mathrm{av} .} 7.58 \mathrm{~cm} ; \int_{0}^{t} \omega^{2}\right.$.dt $=7 \cdot 17$ $\left.\times 10^{8} \mathrm{rad}^{2} \mathrm{~s}^{-2}\right)$. The distribution of cell numbers $(\bigcirc)$, mean cell volume $(\square)$, modal cell volume $(\square)$ and sucrose concentration $(O)$ are shown. The line through the sucrose concentration data points indicates the computed profile of the equivolumetric gradient.

exponentially growing culture of $1.245 \mathrm{~g} \mathrm{ml}^{-1}$. An equivolumetric gradient (Pollack \& Price, 1971), therefore, was prepared and the variations in cell number, mean cell volume and modal cell volume after centrifugation of cells from an exponentially growing culture through such a gradient are shown in Fig. 1. The distribution of cell concentration across the gradient was of similar shape to the size distribution of the culture before fractionation (Fig. $2 a$ ) and the cells were dispersed over most of the gradient. The mean and modal cell volumes increased in each successive fraction, the former from $10.4 \mu \mathrm{m}^{3}$ to $25.4 \mu \mathrm{m}^{3}$, and the latter from $7.54 \mu \mathrm{m}^{3}$ to $24.6 \mu \mathrm{m}^{3}$. The size distributions of the unfractionated exponentially growing culture and of some of the fractions obtained are shown in Fig. 2. In fractions 1 to 13, the modal volume was significantly smaller than the mean cell volume (Fig. 1) due to positive skewing of the distributions (especially, for example, in Fig. $2 b, c, d$ ). The degree of skewness decreased across the gradient. Coefficients of variation $(C)$ were calculated for each fraction and values are given for those illustrated in Fig. 2. The coefficient of variation is a measure of the resolution achieved; all values obtained for fractions were smaller than those of the exponential culture $(C=0 \cdot 52$, Fig. $2 a$ ). The values for the first few fractions were relatively high (about 0.46 ) compared to later fractions (about 0.38 ) and probably reflect the skewness of the volume distributions in these early fractions.

\section{Isopycnic fractionations}

Preliminary experiments were performed to determine the mean buoyant density of cells from exponentially growing cultures of $S$. halophilus to facilitate the construction of an equivolumetric gradient. Centrifugation of cells on 5 to $40 \%$ (w/v) gradients of Ficoll and various dextrans indicated that the buoyant density of $S$. halophilus was unusually high $\left(\rho>1.18 \mathrm{~g} \mathrm{ml}^{-1}\right)$. Fractionations on Ficoll or dextran gradients at greater concentrations were precluded by the great viscosity of such solutions; Urografin was selected as an alternative gradient material because of its high density combined with low viscosity.

Figure 3 shows the distribution of cell numbers and volumes recorded after isopycnic banding of $S$. halophilus in a 26 to $44 \%$ (w/v) Urografin gradient in $3 \%(\mathrm{w} / \mathrm{v}) \mathrm{NaCl}$. Again, the 



(e)

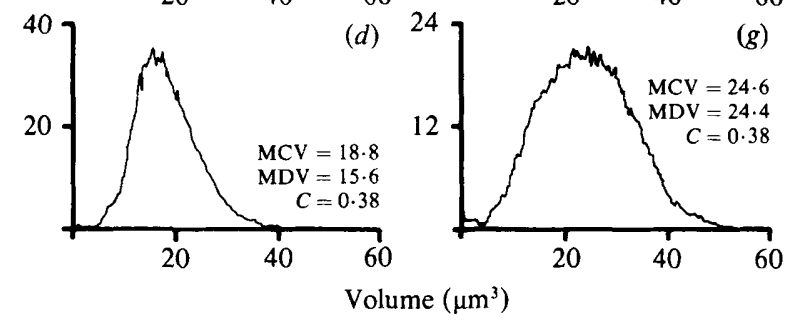

Fig. 2. Frequency distributions of cell volumes for an exponentially growing culture of $S$. halophilus, and of populations obtained by rate-zonal fractionation of such a culture into various size classes. Measurements were made in each of 100 size classes and the area below the curves normalized. The size distributions shown are for $(a)$ an exponentially growing culture, and $(b$ to $g$ ) for the cells eluted in $(b)$ fraction $1,(c)$ fraction $4,(d)$ fraction $7,(e)$ fraction $8,(f)$ fraction 13 and $(g)$ fraction 17 in the experiment shown in Fig. 1. The mean cell volume (MCV), modal cell volume (MDV) and the coefficients of variation in the mean cell volume $(C)$ of each of these distributions are given in $\mu \mathrm{m}^{3}$.

distribution of cell numbers resembled in shape the size distribution of the exponentially growing culture (Fig. $4 a$ ). Cells of the least density were found to be the smallest in size; the mean and modal cell volumes were 10.4 and $7.35 \mu \mathrm{m}^{3}$, respectively, at a density of $1.165 \mathrm{~g} \mathrm{ml}^{-1}$ (Fig. 3). Cell size increased with density (and volume eluted) to a mean volume of $20.4 \mu \mathrm{m}^{3}$ and a modal cell volume of $19.8 \mu \mathrm{m}^{3}$ at a density of $1.256 \mathrm{~g} \mathrm{ml}^{-1}$. The size distributions of the exponentially growing cultures and of six of the fractions obtained in this separation are shown in Fig. 4. The size distributions of the fractions were unimodal, with the possible exception of some of the early fractions (i.e. those of least density) where a second population, with a mode of roughly $18 \mu \mathrm{m}^{3}$, may be present (Fig. $4 b$ ). Consequently, the coefficients of variation for the first four fractions were high (e.g. $0 \cdot 49$, Fig. $4 b$ ) but in later fractions (numbers 7 to 14 ) they were comparable with those obtained in rate separations (e.g. 0.38, Fig. $4 g$ ). The value of $1.245 \mathrm{~g} \mathrm{ml}^{-1}$ for the mean buoyant density of $S$. halophilus obtained initially was used in calculating the profile of the equivolumetric gradient. Later, more detailed, experiments (involving measurements in over 80 fractions) gave the slightly lower value of $1.225 \mathrm{~g} \mathrm{ml}^{-1}$

\section{Accumulation of macromolecules and synthesis of RNA during the cell cycle of $S$. halophilus}

The patterns of DNA synthesis obtained in three cell cycle analyses performed by rate fractionation and in five by isopycnic fractionation, are shown in Fig. $5 a$ and Fig. $5 b$, 


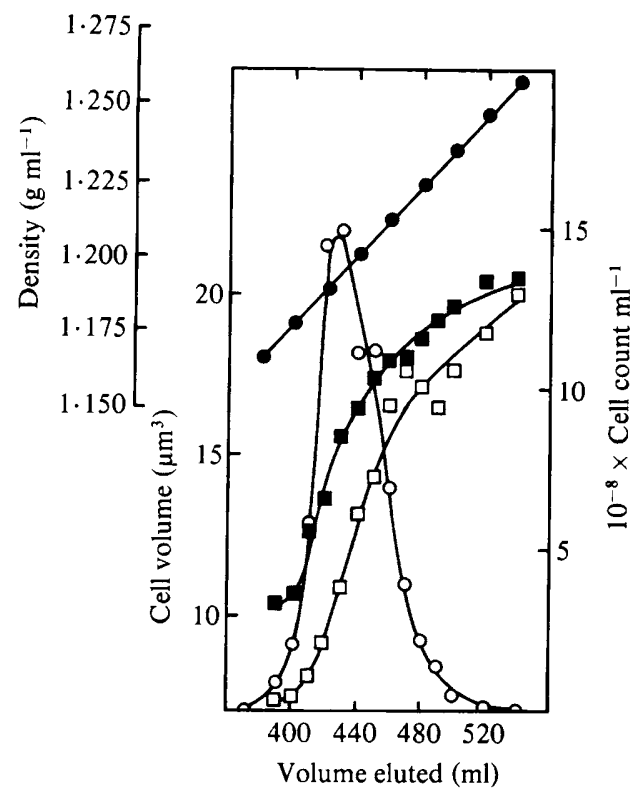

Fig. 3. Isopycnic-zonal fractionation of cells from an exponentially growing culture of $S$. halophilus using a BXIV rotor. Roughly $13 \mathrm{ml}$ of a concentrated cell suspension containing $1.16 \times 10^{10}$ cells ml $^{-1}$ was loaded on the Urografin gradient and centrifuged for $60 \mathrm{~min}$ at 30000 r.p.m. $(25000 \mathrm{~g}$, radius at sample zone $2.48 \mathrm{~cm} ; \int_{0}^{t} \omega^{2} . \mathrm{dt}=3.56 \times 10^{10} \mathrm{rad}^{2} \mathrm{~s}^{-2}$ ) and $4{ }^{\circ} \mathrm{C}$. Cell numbers $(O)$, mean cell volume $(\square)$, and modal cell volume $(\square)$ were determined in each fraction. Density $(O)$ was measured in the component solutions of the gradient before loading into the rotor.

respectively. In both cases, the DNA content was constant at about $20 \mathrm{fg}$ per cell for the majority of the cell cycle (i.e. in samples with mean cell volumes between 9 and $16 \mu \mathrm{m}^{3}$ ). In the rate separations, the DNA content showed a slight increase to $28 \mathrm{fg}$ per cell (Fig. $5 a$ ) in cells larger than $16 \mu \mathrm{m}^{3}$; however, in the isopycnic separations, a rapid increase in DNA to roughly twice the basal level was observed (Fig. $5 b$ ). This indicated that DNA replication occurred late in the cell cycle. The cells with mean volumes of less than $9 \mu \mathrm{m}^{3}$ showed markedly reduced amounts of DNA in both types of fractionation. Phase-contrast microscopy showed that cells in these early fractions were normal in morphology, being small unbudded cells, and were interpreted as immature buds, which had been inadvertently separated from their mother cells (by disruption of the sterigmata during either the harvesting or fractionation procedure) before receiving their DNA complement. This would indicate that mitosis also occurs late in the cell cycle, since the mean cell volume of these fractions approached that of the neonatal cells. Therefore, nuclei were stained with 4',6-diamidino-2-phenylindole using the methods of Williamson \& Fennell (1975). The vast majority of the cells stained (approx. $20 \%$ in an exponential culture) contained only one nucleus, even those with large buds. Occasionally, cells were observed with two nuclei, one of which was found in the large mature bud that such large cells always possessed, again suggesting that mitosis occurs late in the cell cycle of this yeast.

In contrast to DNA, total protein showed a continuous pattern of accumulation with an overall doubling in amount per cell during the cell cycle when analysed by either rate fractionations (Fig. $5 e$ ) or by isopycnic fractionations (Fig. $5 f$ ). In each case, the bold smooth line is a theoretical curve describing an exponential rate of protein accumulation, which doubles over the cell cycle (taken to be the twofold range in mean cell volume, 9.5 to $19 \mu \mathrm{m}^{3}$, for the reasons presented below). This was the null hypothesis. The reproducibility of the total protein assay (coefficient of variation 0.066 ) is indicated by the extent of two standard deviations above and below, respectively, the theoretical curve. The experimental data showed satisfactory fits to the exponential model at the $95 \%$ confidence level. However, other models, for example a linear rate of protein accumulation with respect to cell volume, would give equally valid fits. Similar results were observed in three rate separations, and at least 12 isopycnic separations. 



Fig. 4. Size distributions of the cells recovered from some of the fractions from the isopycnic-zonal separation shown in Fig. 3. The size distribution of cells from $(a)$ the exponentially growing culture, and from $(b)$ fraction $2,(c)$ fraction $4,(d)$ fraction $6,(e)$ fraction $8,(f)$ fraction 11 and $(g)$ fraction 12 are shown. The mean cell volume (MCV), modal cell volume (MDV) and the coefficients of variation in the mean cell volume $(C)$ of each of these distributions are given in $\mu \mathrm{m}^{3}$.

Total cellular RNA accumulated continuously during the last 0.75 of the cycle, but was briefly elevated in cells with a mean volume of about $10 \mu \mathrm{m}^{3}$ in both rate (Fig. $5 c$ ) and in isopycnic fractionations (Fig. 5d). A doubling of RNA content over the twofold range of cell volumes was not obtained. Results in another rate separation and in four isopycnic separations were essentially the same.

These surprising results were further investigated by examining the rate of synthesis of RNA using a double-label technique, in which the RNA was uniformly labelled with $\left[{ }^{3} \mathrm{H}\right]$ uracil and pulsed with $\left[{ }^{14} \mathrm{C}\right]$ uracil. Figure $6(a)$ shows that the activity of $\left[{ }^{3} \mathrm{H}\right]$ uracil on a per cell basis (equivalent to the amount of RNA present) exhibited the same pattern of variation through the cell cycle as did RNA determined colorimetrically (see Fig. $5 c, d$ ). RNA content was high in cells of about 10 to $11 \mu \mathrm{m}^{3}$ mean volume, then declined and rose in the last 0.5 of the cycle. The use of $\left[{ }^{14} \mathrm{C}\right]$ uracil to pulse-label RNA showed the rate of synthesis to be relatively constant over most of the cycle (Fig. $6 b$ ). However, these measurements rely on a quantitative recovery of RNA, whilst the ratio ${ }^{14} \mathrm{C} /{ }^{3} \mathrm{H}$ provides an internal control for this variable and is shown in Fig. $6(c)$. The ratio oscillated during the cell cycle but, unlike the results of Elliott \& McLaughlin (1978), is not indicative of periodic RNA synthesis, but of fluctuations in total RNA content. A value of 0.26 for the ratio of ${ }^{14} \mathrm{C} /{ }^{3} \mathrm{H}$ was obtained for the exponential culture (Fig. $6 c$ ). In a duplicate experiment, similar results were obtained. 


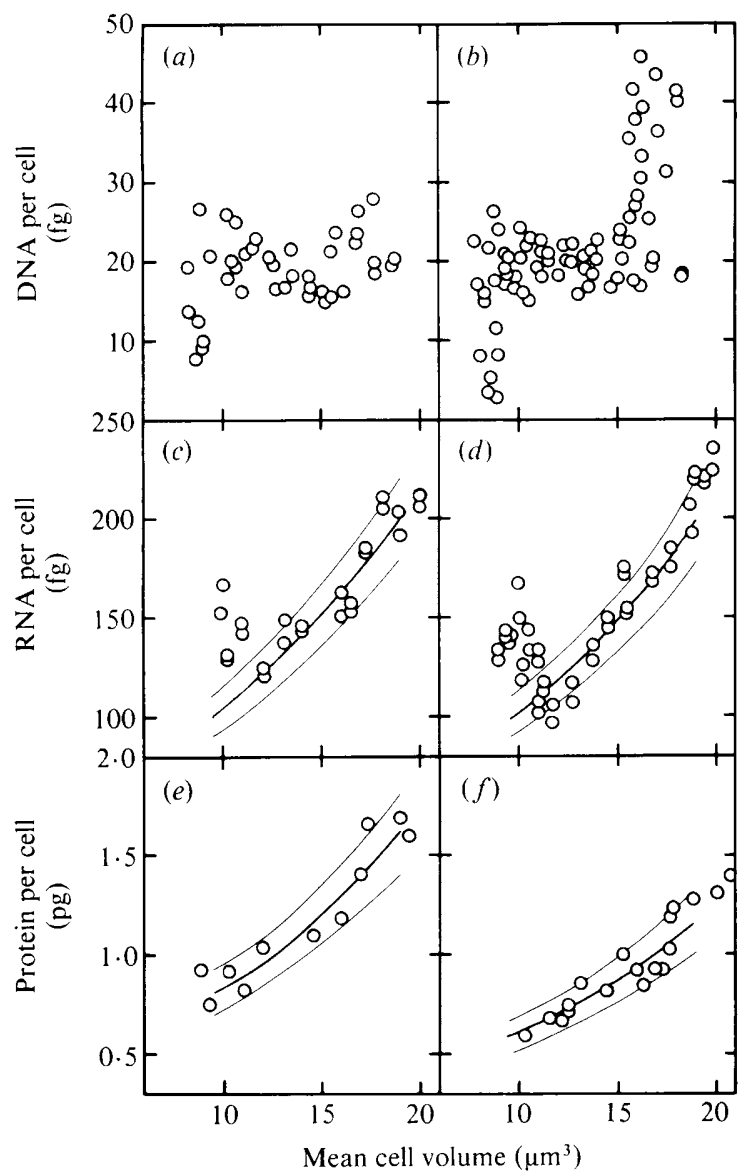

Fig. 5. Patterns of macromolecular accumulation during the cell cycle of $S$. halophilus. The DNA contents of cells in fractions from $(a)$ rate and $(b)$ isopycnic separations of exponentially growing cultures are shown. The figure contains data from three rate separations and five isopycnic separations; each point is the mean of duplicate determinations. The RNA contents of cells in fractions from $(c)$ rate and $(d)$ isopycnic separations, and of protein in $(e)$ rate and $(f)$ isopycnic separations are shown. The central bold line of the three curves drawn through the experimental data of $(c),(d),(e)$ and $(f)$ represents an exponential rate of increase in either RNA or protein content that doubles over the twofold increase in cell volume 9.5 to $19 \mu^{3}$. These lines are the null hypotheses. The two lines above and below these central lines indicate the extent of two standard deviations from the theoretical curves. The data points for total protein are the means of four determinations.

\section{DISCUSSION}

The mean buoyant density of $S$. halophilus from exponentially growing cultures was $1.225 \mathrm{~g} \mathrm{ml}^{-1}$, a value much greater than those reported for other yeasts. Hartwell (1970) reported banding of Saccharomyces cerevisiae in Renografin (essentially of the same composition as Urografin) in the density range 1.11 to $1.15 \mathrm{~g} \mathrm{ml}^{-1}$. The buoyant density range of Schizosaccharomyces pombe is given as 1.040 to $1.110 \mathrm{~g} \mathrm{ml}^{-1}$ by Poole \& Lloyd (1973), and that of Candida utilis can be calculated as 1.084 to $1.095 \mathrm{~g} \mathrm{ml}^{-1}$ from Nurse \& Wiemken (1974) using the data of Lieblová et al. (1964) for the densities of dextran solutions. More importantly, all report a more complex pattern of density fluctuation through the cell cycle. In both Sacch. cerevisiae and C. utilis, the cells of least density are those with very large buds, while those of greatest density have small buds, and fractions of intermediate density are mixed populations of cells at other cell cycle stages (Wiemken et al., 1968; Wiemken et al., 1970; Hartwell, 1970). Density decreases during the first three quarters of the cell cycle of Sch. pombe but increases during the last quarter 


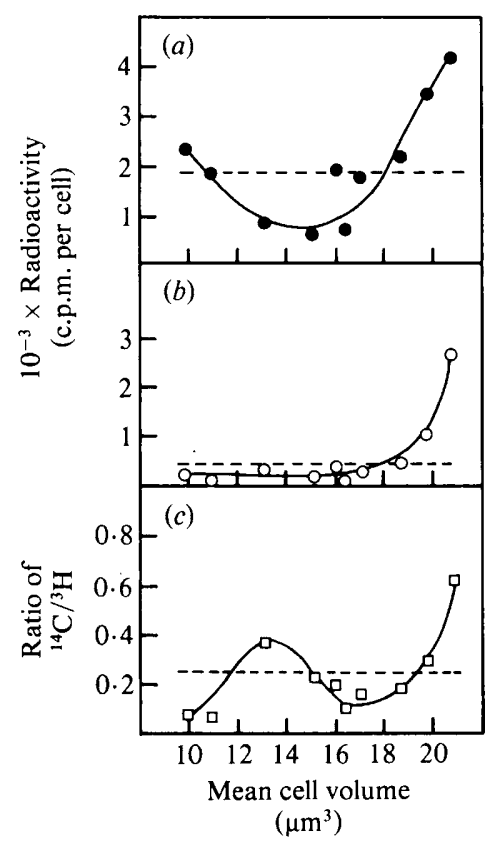

Fig. 6. The rate of synthesis of RNA during the cell cycle of $S$. halophilus. RNA was labelled for $15 \mathrm{~h}$ with $\left[{ }^{3} \mathrm{H}\right]$ uracil, and pulse-labelled for $30 \mathrm{~min}$ with $\left[{ }^{14} \mathrm{C}\right]$ uracil. The cells were fractionated by equilibrium centrifugation, and the radioactivity per cell determined. (a) Incorporation of the long-term label and $(b)$ incorporation of the pulse label. $(c)$ Ratio of pulse to long-term label. In each, the dashed horizontal line indicates the corresponding value found in an exponentially growing culture.

(the constant volume stage) (Mitchison, 1957; Poole \& Lloyd, 1973). However, patterns of continuously increasing density throughout the cell cycle, similar to those in $S$. halophilus, have been observed in erythrocytes (Leif \& Vinograd, 1964) and in Chlorella (Sitz et al., 1970). The high buoyant density of $S$. halophilus may be a consequence of its osmotic tolerance. Some marine and salt-tolerant algae accumulate glycerol, as an osmotic stabilizer, to high levels $(50 \%$ of dry weight) (Ben-Amotz, 1973; Williams et al., 1979).

Comparison of the resolution attained in these fractionations with those attained by previous workers may be made by calculating the ratio of the largest cells separated to the smallest cells separated (Scott et al., 1980). Values of 1.97 (for mean volume) and 3.06 (for modal volume) were obtained for the data of Fig. 1, but were as high as 2.68 and 3.31 , respectively, in other rate separations. In the isopycnic fractionation shown in Fig. 3, the ratio for mean cell volumes was 1.96 and for modal cell volumes 2.69 but were, in general, greater than in rate separations. Maximal values of 3.98 and 4.87 for mean and modal volumes, respectively, were obtained. These values compare favourably with those calculated from the data presented in previous studies. For rate separations of Sacch. cerevisiae, these are 2.25 (mean cell volume; Sebastian et al., 1971) and 4.83 (median volume; Mitchison \& Carter, 1975), and for Sch.pombe 1.75 (mode of cell length; Wells \& James, 1972) and 2.13 (mean cell volume; Mitchison \& Carter, 1975). Data for isopycnic separations are sparse, but Poole \& Lloyd (1973) obtained a ratio of 1.94 for the modal volume in a fractionation of Sch. pombe.

This ratio is, however, a poor measure of resolution because, as in any calculation that depends on the measurement of extreme values, the inherent error is great, and the ratio says nothing about the resolution of sizes in fractions between the two extremes. A much better measure of resolution is to compare the dispersion of cell sizes in each fraction with that found in the exponentially growing cultures. This may be done by measuring the ratio between the coefficients of variation in size of each fraction $\left(C_{\mathrm{f}}\right)$ and of the exponential culture $\left(C_{\mathrm{e}}\right)$. The smaller the ratio, the better the resolution achieved. This method has the advantage of allowing 
the resolution to be measured in each fraction. In rate separations of $S$. halophilus, values for this ratio $\left(C_{\mathrm{f}} / C_{\mathrm{e}}\right)$ vary across the gradient, being relatively high in the first few fractions before falling in the remaining fractions to around $0 \cdot 71$. An average ratio of 0.78 was obtained for 117 fractions from four independent experiments. In isopycnic fractionations, this ratio ranges from 0.89 in the first few fractions to about 0.69 in the remainder, and an average value of 0.76 was obtained for 107 fractions from four independent experiments. Unfortunately, the literature contains very few experiments for which this ratio may be calculated. Ratios of between 0.75 (in early fractions, i.e. unbudded cells) to 0.56 (in late fractions) were calculated from the data of Sebastian et al. (1971) for a rate separation of Sacch. cerevisiae, and from the data of Poole \& Lloyd (1973) ratios across the gradients of 0.86 to 1.89 in rate separations, and of 1.13 to 1.24 in isopycnic separations of Sch. pombe may be calculated.

Cell volume was used as a measure of cell age but the relationship between the two has to be established. The volume of cells at birth (i.e. the neonatal cells) may be estimated from the size distributions of exponentially growing cultures in three ways: (1) From the approximation of Kubitschek et al. (1967) that

$$
\bar{V}_{\mathrm{b}}=\bar{V} \ln 2
$$

where $\bar{V}$ is the mean volume of cells in the exponential culture and $\bar{V}_{\mathrm{b}}$ the mean volume of cells at birth. The mean cell volume of an exponentially growing culture at the time of harvesting in 10 experiments was $\left( \pm\right.$ S.D.) $15.6 \pm 0.42 \mu \mathrm{m}^{3}$ and the modal volume $10.0 \pm 0.76 \mu \mathrm{m}^{3}$. This gives a value of $10.8 \mu \mathrm{m}^{3}$ for the mean of neonatal cells; however this value is an overestimate, since an ideal size distribution is assumed. (2) A better estimate is given by the modal volume of the exponential culture itself, though this still gives a slight overestimate of the true value (Koch \& Blumberg, 1976). (3) The best estimate is obtained by determining the area under the size distribution curves between cell volumes of $V$ and $2 V$, for all values of $V$. The value of $V$ which gives the greatest enclosed area is the neonatal cell volume (Bugeja, 1981). Using this method, a value of $9.5 \mu \mathrm{m}^{3}$ for the neonatal cell volume was obtained.

Applying the Campbell (1957) principle of balanced growth, the volume of cells at division is twice the neonatal volume, i.e. $19 \mu \mathrm{m}^{3}$. The relationship between size and age at intermediate values was determined using a mathematical analysis of the distributions of cells in culture fractionations. The analysis was made by obtaining the size distribution for the ideal population of cells (i.e. cells which show no variation in doubling times or size at division) by integration of the observed size distributions for the cells in successive samples from a culture fractionation. This ideal distribution is then transformed to give the relationship between cell size and cell age. The assumptions made are: (1) the fractionation is of an exponentially growing culture; (2) each cell divides into a known number of daughters (two for $S$. halophilus); and (3) the variability between cell age and size is constant for all ages. The detailed theory of this analysis has been published elsewhere (Bugeja, 1981). The results of this analysis for rate and isopycnic fractionations are shown in Fig. 7. Both analyses are in good agreement and show an approximately hyperbolic relationship between cell size and age.

The development of various macromolecular components during the cell cycle of $S$. halophilus was investigated. DNA was replicated late in the cell cycle; this was most clearly seen in isopycnic fractionations where the DNA content of cells increased rapidly in cells with volumes greater than $16 \mu \mathrm{m}^{3}$. This indicates that the resolution of cell cycle events, particularly those late in the cycle, was better in isopycnic fractionations, and since these separations are technically easier to perform (gradients were less viscous, and the gradient shape and length of centrifugation were not critical), preference was given to them as a method of cell cycle analysis. The patterns of RNA and protein accumulation were similar in both types of fractionation. Total protein increased continuously in a manner that was consistent with an exponential rate of increase, but the RNA content exhibited a transient, single maximum at the beginning of the cycle. Using the double-label method, the rate of RNA synthesis appeared to oscillate, but the changing ratio of short-term to long-term label was probably largely due to the varying levels of cellular RNA during the cell cycle. RNA content was transiently elevated in cells with a volume of about $10 \mu \mathrm{m}^{3}$. These results are in contrast to those of Elliott \& McLaughlin $(1978,1979)$ with 


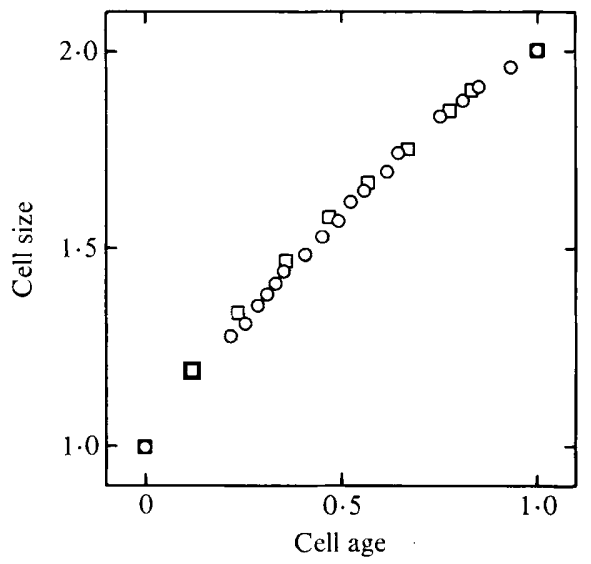

Fig. 7. The relationship between cell age and cell size for $S$. halophilus established by analysis of size distribution data from rate $(\square)$ and isopycnic $(O)$ fractionations of exponentially growing cultures.

Sacch.cerevisiae, and indeed most previous work (for reviews see Mitchison, 1971; Lloyd et al., 1982) in which total protein and RNA have been found to accumulate continuously throughout the cell cycle. However, oscillations in the amounts of these components were observed during the growth of synchronous cultures of $C$. utilis (Lloyd et al., 1981) and Acanthamoeba castellanii (Edwards \& Lloyd, 1980). These authors suggested that the oscillations represented an ordered sequence of sub-cycles, in which discrete phases of protein synthesis and degradation alternate.

Most of this work was performed during the tenure of an SERC Research Studentship (to I.S.). The BXIV zonal rotor was purchased with funds from the University of London Central Research Fund. We also thank Dr V. Bugeja for assistance in the analysis of Fig. 7, Dr P. T. Saunders for advice on statistics, and Professor J. M. Mitchison for constructive criticism and helpful comments.

\section{REFERENCES}

Bazin, M. J., Richards, L. \& SAunders, P. T. (1975). Automated analysis of microbial size distribution data. Proceedings 10th International Coulter Electronics Symposium, pp. 426 435. Harpenden, U.K.: Coulter Electronics.

Ben-Amotz, A. (1973). Photosynthetic and osmoregulation mechanisms in the halophilic alga Dunaliella parva. $\mathrm{Ph} . \mathrm{D}$. thesis, Weizmann Institute of Science, Rehovot, Israel.

Bugeja, V. (1981). Mode of growth of individual cells from size data. $\mathrm{Ph} . \mathrm{D}$, thesis, University of London, U.K.

Burton, K. (1956). A study of the conditions and mechanism of the diphenylamine reaction for the colorimetric estimation of deoxyribonucleic acid. Biochemical Journal 62, 315-323.

CAMpbell, A. (1957). Synchronization of cell division. Bacteriological Reviews 21, 263-272.

Ceriotti, G. (1955). Determination of nucleic acids in animal tissues. Journal of Biological Chemistry 214, $59-70$.

COAKLEY, W. T. \& JAMES, C. J. (1978). A simple linear transform for the Folin-Lowry protein calibration curve to $1.0 \mathrm{mg} / \mathrm{ml}$. Analytical Biochemistry 85, 90 97.

Croes, A. F. (1967). Induction of meiosis in yeast. I. Timing of cytological and biochemical events. Planta 76, 209-226.
EDwards, S. W. \& LlOYD, D. (1980). Oscillations in protein and RNA content during synchronous growth of Acanthamoeba castellanii. FEBS Letters 109, 21-26.

Elliott, S. G. \& Mclaughlin, C. S. (1978). Rate of macromolecular synthesis through the cell cycle of the yeast Saccharomyces cerevisiae. Proceedings of the National Academy of Sciences of the United States of America 75, 4384-4388.

Elliott, S. G. \& Mclaughlin, C. S. (1979). Regulation of RNA synthesis in yeast. III. Synthesis during the cell cycle. Molecular and General Genetics 169, 237-243.

FELL, J. W. (1966). Sterigmatomyces, a new fungal genus from marine areas. Antonie van Leeuwenhoek 32, 99-104.

Giles, K. W. \& Myers, A. (1965). An improved diphenylamine method for the estimation of deoxyribonucleic acid. Nature, London 206, 93.

Hartman, G. C., Black, N., Sinclair R. \& Hinton, R. H. (1974). Gradient material interference in the assay of fractions. In Methodological Developments in Biochemistry, Volume 4, Subcellular Studies, pp. 93102. Edited by E. Reid. London: Longmans.

HaRTwell, L. H. (1970). Periodic density fluctuation during the yeast cell cycle and the selection of synchronous cultures. Journal of Bacteriology 104, 12801285 . 
Herbert, D., Phipps, P. J. \& Strange, R. E. (1971). Chemical analysis of microbial cells. Methods in Microbiology 5B, 209-344.

Hinton, R. H. \& Mullock, B. M. (1975). Physiochemical properties of iodinated density gradient media. In Biological Separations in Iodinated Density Gradient Media, pp. 1-14. Edited by D. Rickwood. London: Information Retrieval.

Hinton, R. H., Mullock, B. M. \& Gilhuus-Moe, C.-C. (1974). The use of metrizamide for the fractionation of ribonucleoprotein particles. In Methodological Developments in Biochemistry, Volume 4, Subcellular Studies, pp. 103-110. Edited by E. Reid. London: Longmans.

InTERnational CRITICAL TABles (1928). Volume III, p. 88. New York: McGraw-Hill.

KOCH, A. L. \& BlumberG, G. (1976). Distribution of bacteria in the velocity gradient centrifuge. Biophysical Journal 16, 389-405.

KubitscheK, H. E., Bendigkeit, H. E. \& LoKen, M. R. (1967). Onset of DNA synthesis during the cell cycle in chemostat cultures. Proceedings of the National Academy of Sciences of the United States of America 57, 1611-1617.

LEIF, R. C. \& VinOGRAD, J. (1964). The distribution of buoyant density of human erythrocytes in bovine albumin solutions. Proceedings of the National Academy of Sciences of the United States of America 51, 520-528.

Lieblová, J., Beran, K. \& Streiblová, E. (1964). Fractionation of a population of Saccharomyces cerevisiae yeasts by centrifugation in a dextran gradient. Folia microbiologica 9, 205-214.

Lloyd, D., EdWaRds, S. W. \& Williams, J. L. (1981). Oscillatory accumulation of total cellular protein in synchronous cultures of Candida utilis. FEMS Microbiology Letters 12, 295-298.

Lloyd, D., PoOle, R. K. \& Edwards, S. W. (1982). The Cell Division Cycle: Temporal Organization and Control of Cellular Growth and Reproduction. London: Academic Press.

MilleR, G. L. \& GASEK, J. M. (1960). Drifts of drops in density gradient columns. Analytical Biochemistry 1, 78-87.

Mrtchison, J. M. (1957). The growth of single cells. I. Schizosaccharomyces pombe. Experimental Cell Research 13, 244-262.

Mrtchison, J. M. (1971). The Biology of the Cell Cycle, pp. 115-158. Cambridge: Cambridge University Press.

Mitchison, J. M. \& Carter, B. L. A. (1975). Cell cycle analysis. Methods in Cell Biology 11, 201-219.

MunRo, H. N. \& DowniE, E. D. (1964). Extraction of protein from tissues during treatment with organic lipid solvents. Archives of Biochemistry and Biophysics 106, 516-524.

Nurse, P. \& Wiemken, A. (1974). Amino acid pools and metabolism during the cell division cycle of arginine-grown Candida utilis. Journal of Bacteriology 117, 1108-1116.

PicketT, A. M. \& Lester, J. C. (1979). The design and construction of a radio-frequency interference enclosure for the Coulter Counter. Laboratory Practice 28, 253-255.

Pollack, M. S. \& Price, C. A. (1971). Equivolumetric gradients for zonal rotors: separation of ribosomes. Analytical Biochemistry 42, 38-47.

PoOLE, R. K. (1977). Fluctuations in buoyant density during the cell cycle of Escherichia coli K12: significance for the preparation of synchronous cultures by age selection. Journal of General Microbiology 98, 177-186.

POOLE, R. K. \& LlOYd, D. (1973). Oscillations of enzyme activities during the cell cycle of a glucoserepressed fission yeast Schizosaccharomyces pombe $972 \mathrm{~h}^{-}$. Biochemical Journal 136, 195-207.

Salmon, I. \& PoOle, R. K. (1978). Growth and cell division of a novel budding yeast, Sterigmatomyces halophilus. Bulletin of the British Mycological Society 12, 121 .

Salmon, I. \& Poole, R. K. (1980). The mitochondrial cytochromes of an unusual budding yeast, Sterigmatomyces halophilus: spectral characterization exploiting fourth-order finite difference analysis. Journal of General Microbiology 117, 315-326.

ScotT, R. I., Gibson, J. F. \& Poole, R. K. (1980). Adenosine triphosphatase activity and its sensitivity to Ruthenium Red oscillate during the cell cycle of Escherichia coli K12. Journal of General Microbiology 120, 183-198.

Sebastian, J., Carter, B. L. A. \& Halvorson, H. O. (1971). Use of yeast populations fractionated by zonal centrifugation to study the cell cycle. Journal of Bacteriology 108, 1045-1050.

SITZ, T. O., KeNT, A. B., Hopkins, H. A. \& SchmidT, R. R. (1970). Equilibrium density-gradient procedure for selection of synchronous cells from asynchronous cultures. Science 168, 1231-1232.

STEWART, P. R., (1975). Analytical methods for yeasts. Methods in Cell Biology 12, 111-147.

WaIN, W. H. \& StaATZ, W. D. (1973). Rates of synthesis of ribosomal protein and total ribonucleic acid through the cell cycle of the fission yeast Schizosaccharomyces pombe. Experimental Cell Research 81, 269-278.

WELLS, J. R. \& JAMES, T. W. (1972). Cell cycle analysis by culture fractionation. Experimental Cell Research 75, 465-474.

Weimken, A., von Meyenburg, H. K. \& Matile, P. (1968). Properties of the vacuole in baker's yeast synchronized with a new method. Acta Faculty of Medicine University of Brunensis 37, 47-56.

Wiemken, A., Matile, P. \& MoOR, H. (1970). Vacuolar dynamics in synchronously budding yeast. Archiv für Mikrobiologie 70, 89-103.

Williams, L. A., Foo, E. L., Foo, A. S., Kunh, J. \& HEDEN, C. G. (1979). Solar bioconversion systems based on glycerol production. In Biotechnology and Bioengineering Symposium 8: Biotechnology in Energy Production and Conservation, pp. 115-130. Edited by C. D. Scott. New York: Wiley.

Williamson, D. H. \& Fennell, D. J. (1975). The use of fluorescent DNA-binding agent for detecting and separating yeast mitochondrial DNA. Methods in Cell Biology 12, 335-351.

ZAMB, T. J. \& RoTH, R. (1977). A modified diphenylamine assay for quantifyıng DNA content. In Yeast, A Newsletter for Persons Interested in Yeast, vol. 26, no. 1, pp. 40-42. Edited by H. J. Phaff. Davis: University of California. 